\title{
Prediction of the Chemical Composition of Fresh Whole Crop Barley Silages by Near Infrared Spectroscopy
}

\author{
Hyung Soo Park, Sang Hoon Lee, Young Cheol Lim, Sung Seo, Ki Choon Choi, Ji Hea Kim, Jong Geun Kim \\ and $\mathrm{Gi}$ Jun Choi
}

National Institute of Animal Science, Cheonan, 330-801, Korea

\begin{abstract}
Near infrared reflectance spectroscopy (NIRS) has become increasingly used as a rapid and accurate method of evaluating some chemical compositions in forages and feedstuff. This study was carried out to explore the accuracy of near infrared spectroscopy (NIRS) for the prediction of chemical parameters of fresh whole crop barley silages. A representative population of 284 fresh whole crop barley silages was used as a database for studying the possibilities of NIRS to predict chemical composition. Samples of silage were scanned at $1 \mathrm{~nm}$ intervals over the wavelength range $680 \sim 2,500 \mathrm{~nm}$ and the optical data were recorded as log $1 /$ Reflectance $(\log 1 / R)$ and were scanned in fresh condition. NIRS calibrations were developed by means of partial least-squares (PLS) regression. NIRS analysis of fresh whole crop barley silages provided accurate predictions of moisture, acid detergent fiber (ADF), neutral detergent fiber (NDF), crude protein (CP) and $\mathrm{pH}$, as well as lactic acid content with correlation coefficients of cross-validation $\left(\mathrm{R}^{2} \mathrm{cv}\right)$ of $0.96,0.81,0.79,0.84,0.72$ and 0.78 , respectively, and standard error of cross-validation (SECV) of 1.26 , 2.83, 2.18, 1.19, 0.13 and $0.32 \%$ DM, respectively. Results of this experiment showed the possibility of the NIRS method to predict the chemical parameters of fresh whole crop barley silages as a routine analysis method in feeding value evaluation and for farmer advice.
\end{abstract}

(Key words : Silage, Barley, Near infrared spectroscopy, Feed value, Fermentation)

\section{I . INTRODUCTION}

Whole crop barley silage is important forage in cattle feeding programs, not only in winter rations but also as supplement during the grazing period in Korea.

Round bale silage is relatively a new method of preserving forage in Korea. Silage is the material produced by the controlled microbial fermentation of a crop of high moisture content in a process known as ensilage. Quality of silages is commonly evaluated on the basis of their $\mathrm{pH}$, $\mathrm{NH}_{3}-\mathrm{N}$ and concentrations of certain short-chain organic acids.

Compared to traditional chemical analysis, near infrared reflectance spectroscopy (NIRS) is rapid and cost efficient, without the destruction of samples and the use of hazardous chemicals. To increase the utilization of NIRS in forage field, sample preparation methods is very important. Analysis of feeds and silages by NIRS traditionally involves the drying and milling of the sample. In the case of wet silage samples, heat drying could result in losses of volatile substance (McDonald et al., 1991).

Using NIRS directly on undried silage would increase error by difference in sample particle size, temperature and water content. These problems can be overcome by grinding silages in frozen state with dry ice or liquid nitrogen, but such a procedure is time-consuming and inconvenient due to cleanup required between samples and the need to thaw the sample for subsequent use (Park et al., 2002; Reeves et al., 1989). Also, advances in chemometrics software, spectral data transformation for scatter correction and partial least squares regression have minimized some of the interference of particle size variation and water absorption presented by wet silage samples (Baker et al., 1994; Gordon et al., 1998; Shenk and Westerhaus, 1995).

Although prediction of composition of dried samples has been carried out for a number of years, the direct analysis of undried silages by NIR spectroscopy has the major advantages of reducing time of sample preparation and of reporting the results (Kennedy et al., 1996; Dela Roza et

* Corresponding author: Hyung Soo Park, National Institute of Animal Science RDA, Cheonan 330-801, Korea. Tel: +82-41-580-6753, Fax: +82-41-580-6757, E-mail: anpark69@korea.kr 
al., 1996; Shenk and Westerhaus, 1995).

This study aims to investigate the possibility of NIRS to predict the chemical composition and fermentation parameter of whole crop barley silage, and to establish NIRS calibrations on fresh samples.

\section{П. MATERIALS AND METHODS}

\section{Collection and preparation of the silage samples}

Whole crop barley silage samples $(\mathrm{n}=284)$ were collected from cattle farms and total mixed ration company in Korea during 2010 2012. When the samples were collected, information was recorded about the date and stage of maturity at harvest, type of ensiling structure and the use of additives. The samples were frozen as soon as arrived at the laboratory, and stored frozen $\left(-20^{\circ} \mathrm{C}\right)$ until analyzed. Prior to NIRS scanning of the fresh samples, the silages were thawed at $4^{\circ} \mathrm{C}$ and cut in pieces of 3 to $5 \mathrm{~cm}$ in order to be packed easily in the sample cell. A subsample of each silage was dried in a forced-air oven at $65^{\circ} \mathrm{C}$ for $78 \mathrm{~h}$ and milled to pass a $1 \mathrm{~mm}$ screen for subsequent chemical analysis.

\section{NIRS scanning and statistical analysis}

All work was performed on a NIRS system SPECTRASTAR ${ }^{\mathrm{TM}}$ 2500 (Unity scientific, USA). The fresh silage samples were packed in a rotating circular quartz cell of $10 \mathrm{~cm}$ diameter. Each of the 284 silage samples was scanned as $\log 1 / \mathrm{R}$ over the wavelength range 680 to $2500 \mathrm{~nm}$ at $1 \mathrm{~nm}$ intervals and the average spectrum was recorded.

The mathematical treatment of the spectral data was performed using UCAL software (Unity scientific, USA). NIRS calibrations were developed by means of partial least-squares (PLS) regression (Shenk and Westerhaus, 1993). The following mathematical treatments were applied separately and simultaneously and then compared for choosing the best treatment combination: smoothing, derivative, standard normal variate and detrend (SNVD) and normal multiplicative scatter correction (NMSC). Crossvalidation was carried out to select the optimal number of terms in the equation, so avoiding overfitting.
The mathematical treatment $(1,8,8,1)$ applied was, where the first number indicates the order of derivative, the second number is the gap in nm over which the derivatives is calculated, the third number is the number of data points used in the first smoothing, and the fourth number refers to the number of $\mathrm{nm}$ over which the second smoothing is applied. Calibration statistics calculated include the standard error of calibration (SEC), the coefficient of multi determination in calibration (R2), and the standard error of crossvalidation (SECV). The optimal calibrations were selected on the basis of minimizing the SECV.

\section{Wet chemical analysis}

All chemical analysis was carried out concurrently with the scanning. Dry matter (DM), ash, $\mathrm{pH}$ and crude protein (CP) were analysed according to Official methods (AOAC, 1990). Neutral detergent fiber (NDF) and acid detergent fiber (ADF) were analysed following the method of Van Soest et al. (1991). To determine $\mathrm{pH}, 10 \mathrm{~g}$ of plant tissue were macerated in a blender with $100 \mathrm{ml}$ of distilled water. The $\mathrm{pH}$ was measured with an electrometric $\mathrm{pH}$ meter (HI 9024; HANNA Instrument Inc., UK).

Prior to analysis for short-chain organic acids, transfer 20 $\mathrm{g}$ of fresh silage to a $250 \mathrm{ml}$ wide-necked bottle and add $100 \mathrm{ml}$ of distilled water, cap and shake mechanically for 1h, then filter through a Whatman No. 1 fiter paper. Take $5 \mathrm{ml}$ of filtrate, $1 \mathrm{ml}$ of a $2.5 \mathrm{~g} / \mathrm{L}$ solution of pivalic acid (as internal standard) and $2.5 \mathrm{ml}$ of $0.12 \mathrm{M}$ oxalic acid in a $10 \mathrm{ml}$ calibrated flask and dilute to volume. Centrifuge at $2600 \mathrm{~g}$ for $5 \mathrm{~min}$ and inject the supernatant into the gas chromatography (GC).

Short-chain organic acids were determined by GC (6890N, Agilent Co., USA) on a 80/120 mesh Carbopack B-DA/4\% Carbowax (Supelco Inc., Bellefonte, PA, Catalog No. 1-1889) $20 \mathrm{M}$ column treated with trimesic acid in methanol. The gas flow-rate of $24 \mathrm{ml} \mathrm{min}^{-1}$, the oven temperature to 200 ${ }^{\circ} \mathrm{C}$ and $1 \mu$ injections of $0.03 \mathrm{M}$ oxalic acid were made prior to use.

\section{RESULTS AND DISCUSSION}

\section{NIR spectra of silages}


NIR original spectra and first derivative for 284 fresh whole crop barley silages presented in Fig. 1. Two group of peaks were observed in the spectra of fresh barley silage samples, which provided abundant information for calibrations. There were two apparent peaks at about 1,410 and 1,900 $\mathrm{nm}$, which may be attributed to the absorption by water in fresh silage samples. It was concluded that the physical state affected the NIR spectra of silage.

\section{Silage composition}

The number of samples, mean, minimum, maximum value and standard deviation (SD) of the chemical parameters for the calibration set are summarized in Table 1. All data is on a dry matter basis. The silage samples collected for this study showed a wide variation in chemical parameters, as would be expected for a broad prediction. Similar chemical composition of silage reported by Park et al. (2012) for 286 fresh Italian ryegrass silages.

(a)

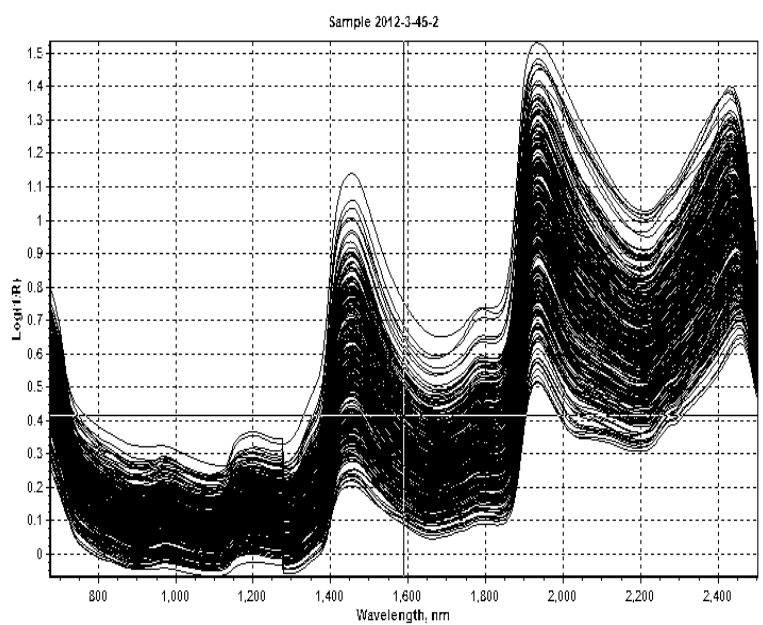

\section{NIRS predictions}

The statistics of the calibrations with the lowest SECV on the whole data set and those of the corresponding calibrations on the calibration set are given in Table 2. The calibrations on the whole data set were good for all parameters, except for crude ash.

High $\mathrm{R}^{2} \mathrm{CV}$ values were found for moisture, $\mathrm{CP}$ and $\mathrm{ADF}$ ranging from 0.81 for $\mathrm{ADF}$ to 0.96 for moisture. Moderate $\mathrm{R}^{2} \mathrm{cV}$ values were obtained for NDF, $\mathrm{pH}$ and lactic acid. These results are comparable to or are a little poorer than those in the studies on fresh grass silages reported by Park et al. (1998) and Sinnaeve et al. (1994).

The calibrations for NDF and $\mathrm{pH}$ have a SD/SECV ratio greater than 2.5, indicating that they are adequate for screening. For moisture, the ratio is even higher than 5.0, making this calibration suitable for quantitative analysis. On the other hand, the ratio is lower than 2.5 for $\mathrm{ADF}, \mathrm{CP}$, crude ash and lactic acid, which means that these calibrations

(b)

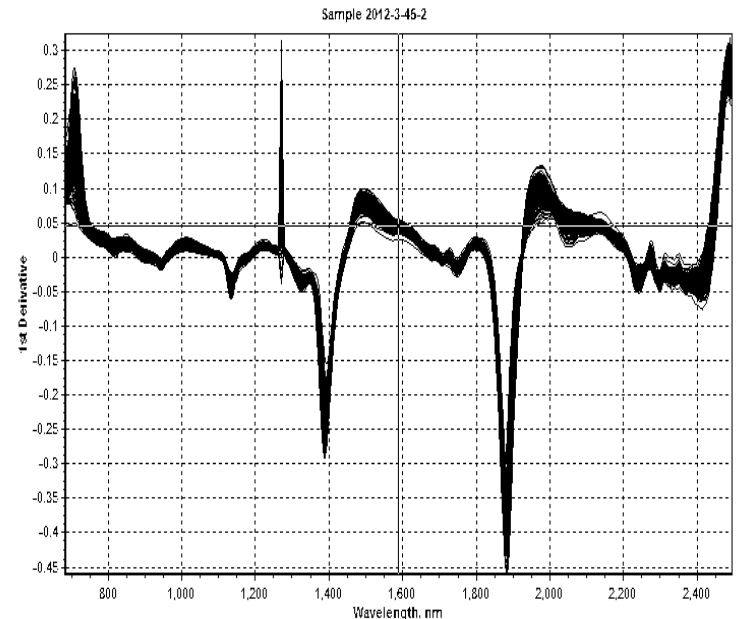

Fig. 1. NIR original spectra as $\log 1 / R$ (a) and as a first derivative (b) for fresh whole crop barley silages.

Table 1. The range in chemical parameters of the 284 fresh whole crop barley silage samples on dry matter basis

\begin{tabular}{lrrrr}
\hline Parameters & Min. & Max. & Mean & SD \\
\hline \hline Moisture (\%) & 33.3 & 83.4 & 61.2 & 8.8 \\
Acid detergent fiber (ADF, \%) & 25.9 & 46.9 & 36.1 & 4.2 \\
Neutral detergent fiber (NDF, \%) & 41.9 & 67.1 & 55.6 & 5.8 \\
Crude protein (\%) & 5.6 & 12.7 & 9.2 & 1.6 \\
Crude ash (\%) & 4.2 & 26.9 & 8.8 & 3.9 \\
pH (1:5) & 3.4 & 7.6 & 4.4 & 0.5 \\
Lactic acid (\%) & 0.01 & 3.01 & 1.41 & 0.6 \\
\hline
\end{tabular}


Table 2. The calibration and validation statistics for the prediction of chemical composition of fresh whole crop barley silages

\begin{tabular}{|c|c|c|c|c|c|c|}
\hline \multirow{2}{*}{ Parameters } & \multirow{2}{*}{$\mathrm{n}$} & \multicolumn{2}{|c|}{ Calibration } & \multicolumn{3}{|c|}{ Validation } \\
\hline & & SEC & $\mathrm{R}^{2}$ & SECV & $\mathrm{R}^{2} \mathrm{CV}$ & SD/SECV \\
\hline Moisture (\%) & 211 & 1.15 & 0.98 & 1.26 & 0.96 & 7.0 \\
\hline Acid detergent fiber (ADF, \%) & 259 & 1.21 & 0.89 & 2.83 & 0.81 & 1.5 \\
\hline Neutral detergent fiber (NDF, \%) & 183 & 2.15 & 0.84 & 2.18 & 0.79 & 2.7 \\
\hline Crude protein (CP, \%) & 283 & 0.68 & 0.86 & 1.19 & 0.84 & 1.3 \\
\hline Crude ash (\%) & 249 & 1.02 & 0.92 & 2.36 & 0.62 & 1.7 \\
\hline $\mathrm{pH}(1: 5)$ & 203 & 0.13 & 0.79 & 0.13 & 0.72 & 3.8 \\
\hline Lactic acid (\%) & 233 & 0.21 & 0.82 & 0.32 & 0.78 & 1.9 \\
\hline
\end{tabular}

SEC = Standard error of calibration, $\mathrm{R}^{2}=$ Multiple correlation coefficient of determination SECV = Standard error of cross validation, $\mathrm{R}^{2} \mathrm{cv}$ $=$ Multiple correlation coefficient of cross validation.
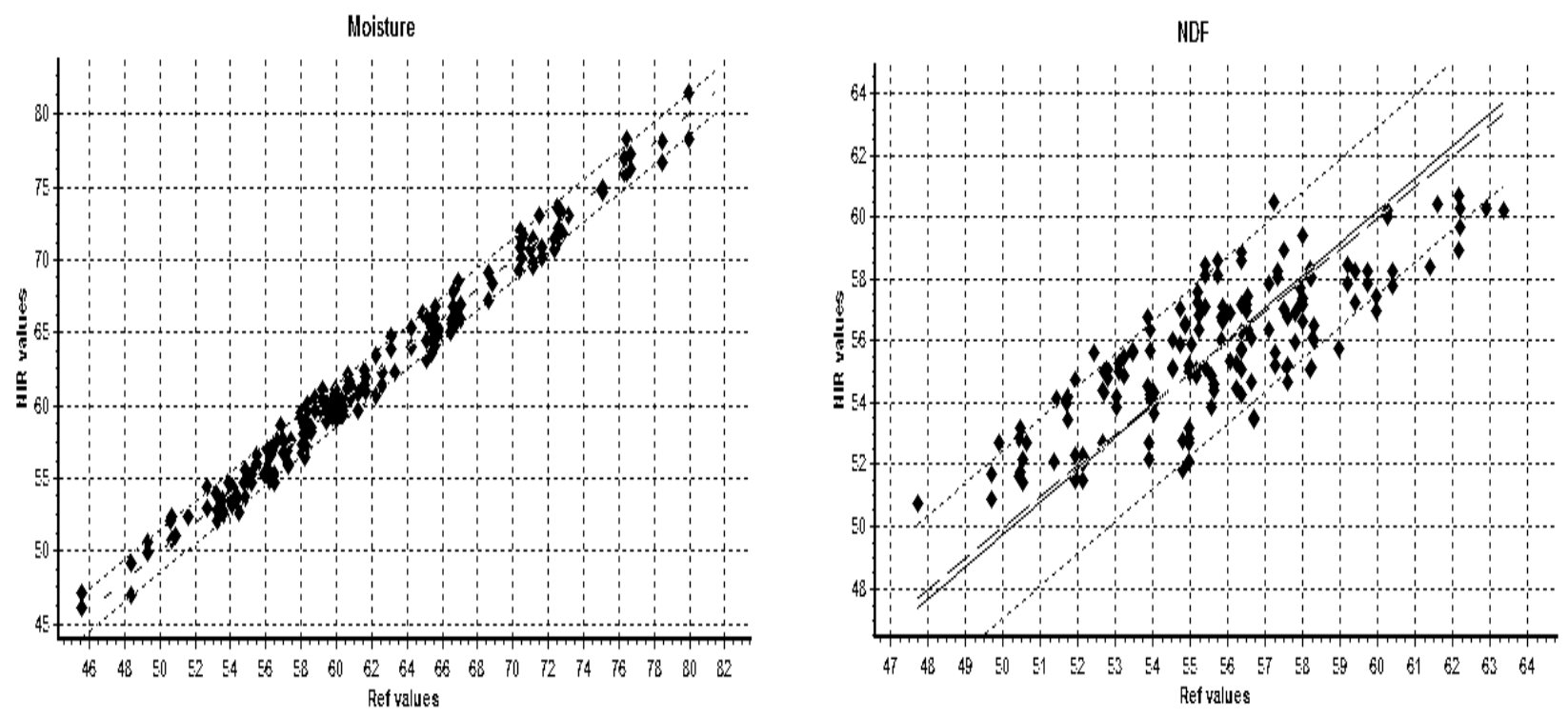

CP
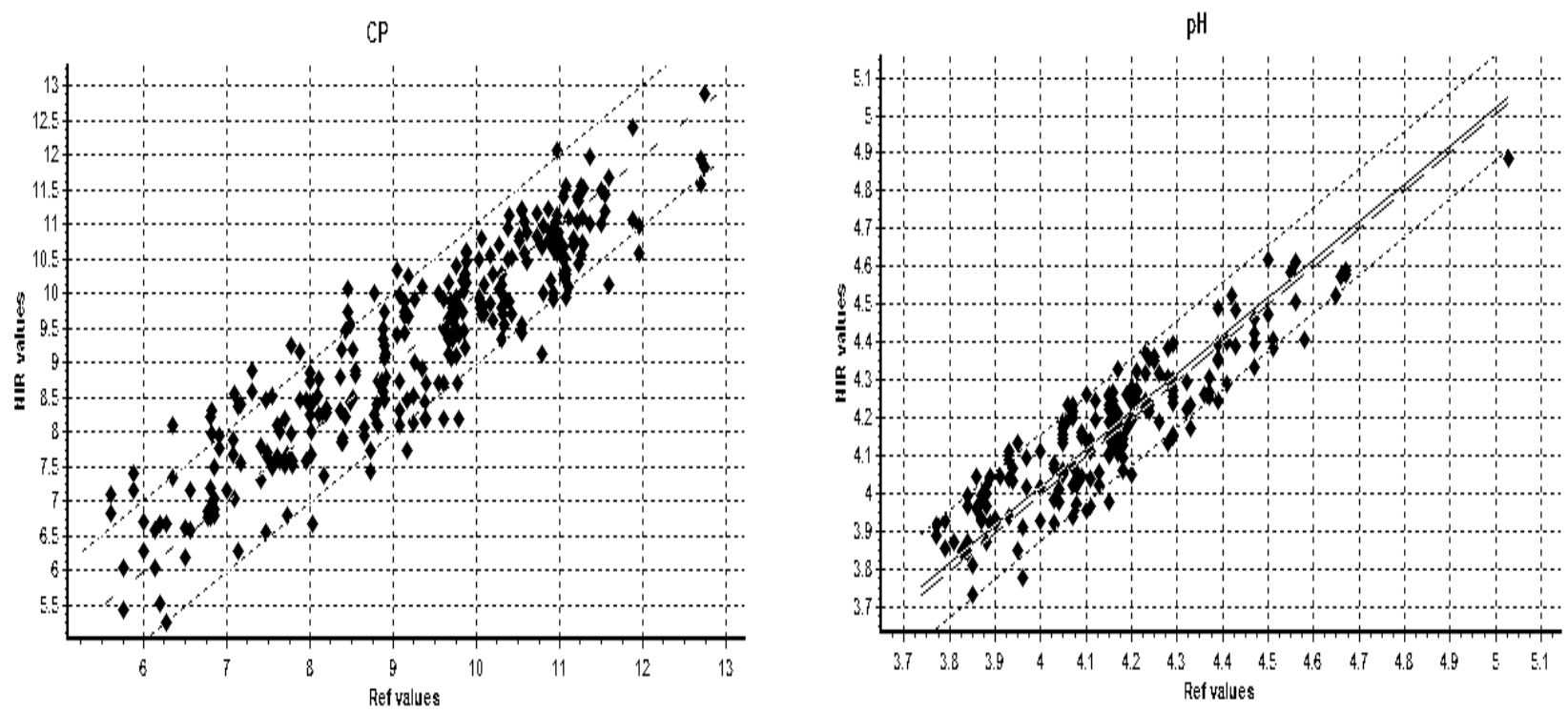

Fig. 2. Relationships between laboratory determined and NIRS predicted moisture, NDF, CP and $\mathrm{pH}$ values of fresh whole crop barley silages. 
are less robust.

Liu, X. and Han, L. (2006) reported NIRS calibrations based on dried samples performed better than those based on fresh samples for most parameters, but not for DM, propionic acid and butyric acid. The latter may be explained by losses of volatile substances, such as short chain fatty acids and alcohols, during oven-drying (McDonald et al., 1991).

The results of this study have shown that NIRS analysis of fresh whole crop barley silages can provide accurate prediction of a wide range of chemical parameters. The calibrations for moisture, NDF and $\mathrm{pH}$ based on fresh samples were good. For the other parameters, the lower accuracy of calibrations based on fresh samples may be due to the heterogeneity of the plant materials, particle size effects or spectral peak broadening by the large amount of water present.

Although NIRS analysis of fresh silages is less accurate, it is more convenient to use fresh than dried samples, allowing rapid prediction of the composition onsite without drying losses (Reeves and Blosser, 1991). Therefore, this offers considerable potential for using fresh silage analysis in routine advisory systems.

\section{CONCLUSION}

NIRS analysis of fresh whole crop barley silages could provide accurate prediction of a wide range of chemical compositions, including moisture, NDF and $\mathrm{pH}$. Also the NIRS technique could be used to accurately predict the $\mathrm{ADF}, \mathrm{CP}$ and lactic acid of fresh whole crop barley silages. This study presented opportunities for the NIRS technique to characterize the feeding value of fresh whole crop barley silages at different situations in the ruminant feeding system. Although the number of samples used in the present study was not enough to test the ability of NIRS to predict chemical composition of fresh whole crop barley silage, maybe a broader population could be used to improve the robustness of these equations.

\section{REFERENCE}

AOAC, 1990. Association of Official Analytical Chemists, Official
Methods of Analysis. $15^{\text {th }}$ Edition. Washington, DC.

Baker, C.W., Givens, D.I. and Deaville, E.R. 1994. Prediction of organic matter digestibility in vivo of grass silages by near infrared reflectance spectroscopy: Effect of calibration method, residual moisture and particle size. Animal Feed Science Technology. 50:17-26.

De la Roza, B., Martinez, A. Modrono, S. and Santos, B. 1996. Determination of the quality of fresh silage by near infrared reflectance spectroscopy. In Davies, A.M.C., Williams, P. (Eds.), Near Infrared Spectroscopy: The Future Waves, Proceedings of the 7th International Conference on Near Infrared Spectroscopy, Montreal, Canada, 6-11 August 1995, NIR Publications, Chichester, UK. pp. 537-541.

Gordon, F.J., Cooper, K.M. Park, R.S. and Steen, R.W.J. 1998. The prediction of intake potential and organic matter digestibility of grass silages by near infrared spectroscopy analysis of undried samples. Animal. Feed Science Technology. 70:339-351.

Kennedy, C.A., Shelford, J.A. and Williams, P.C. 1996. Near infrared spectroscopic analysis of intact grass silage and fresh grass for dry matter, crude protein and acid detergent fiber. In Davies and Williams (Eds.), Near infrared spectroscopy: The future waves, NIR Publications. Chichester. pp. 524-530.

McDonald, P., Henderson, A.R. and Heron, S.J.E. 1991. The biochemistry of silage, second edn. Chalcombe Publications, Marlow. pp. 340.

Park, H.S., Lee, S.-H., Choi, K.C., Lim, Y.C., Kim, J.G., Jo, K.Y. and Choi, G.J. 2012. Evaluation of the quality of Italian ryegrass silages by near infrared spectroscopy. Journal of The Korean Society of Grassland and Forage Science. 32:301-308.

Park, R.S., Gordon, F.J., Agnew, R.E. and Steen, R.W.J. 1998. The use of near infrared reflectance spectroscopy (NIRS) on undried samples of grass silage to predict chemical composition and digestibility parameters. Animal Feed Science Technology. 72: 155-167.

Park, R.S., Agnew, R.E. and Kilpatrick, D.J. 2002. The effect of freezing and thawing on grass silage quality predictions based on near infrared reflectance spectroscopy. Animal Feed Science Technology. 101:151-167.

Reeves III, J.B., Blosser, T.H. and Colenbrander, V.F. 1989. Near infrared reflectance spectroscopy for analyzing undried silage. Journal of Dairy Science. 72:79-88.

Shenk, J.S. and Westerhaus, M.O. 1993. Monograph: Analysis of Agriculture and Food Products by Near Infrared Reflectance Spectroscopy. Infrasoft International, Port Matilda, PA(USA), pp. 103.

Shenk, J.S. and Westerhaus, M.O. 1995. The application of near 
infrared reflectance spectroscopy (NIRS) to forage analysis. pp. 406-449. In G.C. Fahey, Jr. (ed.) forage quality, evaluation, and utilization. ASA, Madison. WI.

Sinnaeve, G., Dardenne, P., Agneessens, R. and Biston, R. 1994. The use of near infrared spectroscopy for the analysis of fresh grass silage. Journal of Near infrared Spectroscopy. 2:79-84.
Liu, X. and Han, L. 2006. Evaluation of near infrared reflectance spectroscopy (NIRS) for prdicting chemical composition of straw silage. Journal of Animal and Feed Science. 15:329-336.

(Received August 5, 2013/Revised August 29, 2013/Accepted September 10, 2013) 